\title{
EDYTA RUTKOWSKA-TOMASZEWSKA
}

ORCID: 0000-0001-9359-7034

Uniwersytet Wrocławski

Katedra Prawa Finansowego

\section{PRAWO OCHRONY KONSUMENTA * USŁUG FINANSOWYCH W ŚWIETLE ZAŁOŻENIA RACJONALNEGO USTAWODAWCY - KILKA WYBRANYCH UWAG}

\begin{abstract}
Abstrakt: Akty prawa unijnego i krajowego regulujące usługi finansowe coraz częściej mają charakter kompleksowy, gdyż zawierają nie tylko normy dotyczące prawnych warunków dopuszczalności ich wykonywania przez instytucje finansowe, ale także normy regulujące w sposób szczegółowy prawa i obowiązki umów o usługi finansowe, szczególne uprawnienia konsumenta i inne mechanizmy oraz instrumenty jego ochrony, co może budzić wątpliwości. Tworzą one konsumenckie prawo rynku finansowego (prawo ochrony konsumenta usług finansowych) i niewątpliwie może to rodzić wiele sporów na etapie stosowania i interpretacji tego prawa i przyczyniać się także do ograniczania skuteczności przewidywanych przez te regulacje prawnych mechanizmów ochrony konsumenta usług finansowych. Celem niniejszego opracowania jest wskazanie specyfiki tego prawa oraz podkreślenie konieczności jego właściwego stanowienia, stosowania i egzekwowania.
\end{abstract}

Słowa kluczowe: konsument, ochrona konsumenta, usługa finansowa, prawo ochrony konsumenta usług finansowych, egzekwowanie prawa ochrony konsumenta, stosowanie prawa ochrony konsumenta

Jakość to sposób myślenia, który powoduje, że stosuje się i bez przerwy poszukuje najlepszych rozwiązań.

Edward Deming

* Na potrzeby niniejszego opracowania przyjęto zasadniczo pojęcie konsumenta w rozumieniu definicji legalnej zawartej w art. $22^{1}$ ustawy z dnia 23 kwietnia 1964 roku - Kodeks cywilny (tekst jedn. Dz.U. z 2019 r. poz. 1145 ze zm.), uznając, że jest nim osoba fizyczna dokonująca z przedsiębiorcą czynności prawnej niezwiązanej bezpośrednio z jej działalnością gospodarczą lub zawodową. 


\section{UWAGI WSTEPPNE}

Motto, które rozpoczyna niniejsze opracowanie, dotyczące prawa ochrony konsumenta usług finansowych (konsumenckiego prawa rynku finansowego), doskonale odzwierciedla sposób realizacji założeń racjonalnego ustawodawcy $\mathrm{w}$ odniesieniu do stanowienia prawa, co następnie ma przełożenie na proces jego stosowania i egzekwowania w czasach dynamicznego przyrostu regulacji prawnych w tym obszarze.

Ostatnio można zauważyć zjawisko inflacji prawa, wzrost regulacji prawnych o różnym charakterze, także mocno rozproszonych, a dotyczących usług finansowych i ochrony konsumenta na rynku finansowym. W Polsce i Unii Europejskiej jest ona wciąż niezwykle istotnym i aktualnym problemem, zarówno w wymiarze regulacyjnym, jak i praktycznym, zwłaszcza w rzeczywistości pokryzysowej, w której dostrzeżono dużą skalę nadużyć instytucji finansowych wobec nich ${ }^{1} . Z$ jednej strony regulacja prawna ochrony konsumenta usług finansowych jest wciąż rozbudowywana i rozszerzana, czego dowodem są najnowsze akty prawa unijnego ${ }^{2}$ oraz implementujące je akty prawa krajowego ${ }^{3}$ (tak zwane ustawy sektorowe ${ }^{4}$ i ustawy

${ }^{1}$ Zamiast wielu zob. Nieprawidłowości na rynku finansowym a ochrona konsumenta. Raport Doradczego Komitetu Naukowego przy Rzeczniku Finansowym, Warszawa, wrzesień 2019, https:// rf.gov.pl/pdf/DKN_Raport_nieprawidlowosci_wrzesien2019.pdf i powoływane tam materiały źródłowe.

2 Dla przykładu można tu wskazać akty prawa unijnego: dyrektywę Parlamentu Europejskiego i Rady 2014/17/UE z dnia 4 lutego 2014 roku w sprawie konsumenckich umów o kredyt związanych z nieruchomościami mieszkalnymi (Dz.U. UE L 60 z 28.2.2014 r., s. 34-85); dyrektywę Parlamentu Europejskiego i Rady (UE) 2016/97 z dnia 20 stycznia 2016 roku w sprawie dystrybucji ubezpieczeń (Dz.Urz. UE L 26 z 2.02.2016 r., s. 19); dyrektywę Parlamentu Europejskiego i Rady 2014/65/UE z dnia 15 maja 2014 roku w sprawie rynków instrumentów finansowych (Dz.U. UE 2014.173.349 z 12.06.2014 r.); dyrektywę Parlamentu Europejskiego i Rady (UE) 2015/2366 z dnia 25 listopada 2015 roku w sprawie usług płatniczych w ramach rynku wewnętrznego (Dz.U. UE L 337 z 23.12.2015 r., s. 35-127).

3 Odpowiednio chodzi o ustawę z 23 marca 2017 roku o kredycie hipotecznym oraz o nadzorze nad pośrednikami kredytu hipotecznego i agentami (Dz.U. z 2017 r. poz. 819), dalej: u.k.h.; ustawę z 15 grudnia 2017 roku o dystrybucji ubezpieczeń (tekst jedn. Dz.U. z 2019 r. poz. 1881 ze zm.), dalej: u.d.u.; ustawę z 29 lipca 2005 roku o obrocie instrumentami finansowymi (tekst jedn. Dz.U. z 2020 r. poz. 89), dalej: u.o.i.f.; ustawę z 19 sierpnia 2011 roku o usługach płatniczych (tekst jedn. Dz.U. z 2019 r. poz. 659), dalej: u.u.p.

${ }^{4}$ Tym mianem określa się ustawy regulujące zasady prowadzenia działalności przez poszczególne rodzaje instytucji finansowych oraz określające dozwolony i przypisany im katalog usług finansowych. Są to między innymi: w odniesieniu do banków — ustawa z 29 sierpnia 1997 roku, Prawo bankowe (tekst jedn. Dz.U z 2019 r. poz. 2357 ze zm.), dalej p.b; w odniesieniu do form inwestycyjnych - ustawa z 29 lipca 2005 roku o obrocie instrumentami finansowymi (tekst jedn. Dz.U. z 2020 r. poz. 89), dalej u.o.i.f.; w odniesieniu do instytucji płatniczych i instytucji pieniądza elektronicznego - ustawa z dnia 19 sierpnia 2011 roku o usługach płatniczych (tekst jedn. Dz.U. z 2019 r. poz. 659), dalej: u.u.p.; w odniesieniu do zakładów ubezpieczeniowych i reasekuracyjnych — ustawa z dnia 11 września 2015 roku o działalności ubezpieczeniowej i reasekuracyjnej (tekst jedn. Dz.U. z 2019 r. poz. 381 ze zm.), dalej. u.dz.u.; w odniesieniu do funduszy inwestycyjnych 
konsumenckie ${ }^{5}$ ). Z drugiej strony rzeczywisty i aktualny stan ochrony konsumenta na rynku finansowym, mierzony skalą ujawnionych nieprawidłowości i nadużyć, nie wygląda zadowalająco. Rodzi to pytanie o to, jakie muszą być podjęte działania, by to zmienić?

Przepisy dotyczące ochrony konsumenta usług finansowych mają w istocie niejednorodny charakter prawny, choć regulują relacje umowne instytucji finansowych z konsumentem. Są one wyrazem ingerencji ustawodawcy w sferę cywilnoprawną, ograniczając mechanizmy kształtowania treści stosunków umownych. Zjawisko „publicyzacji”6 prawa umów o usługi finansowe, będące przejawem konieczności szczególnej ochrony konsumenta usług finansowych, wyraża się w ingerencji w swobodę umów i w zasadę pacta sunt servanda, wprowadzeniu zasady, że postanowienia umów o usługę finansową nie mogą być mniej korzystne dla ich odbiorców (konsumentów i nie tylko) niż przepisy ustawy z sankcją nieważności i nakazem stosowania odpowiednich przepisów ustawy Prawo umów o usługi finansowe, zwłaszcza te konsumenckie, znacznie odbiega bowiem od tradycyjnych i utrwalonych cywilnoprawnych reguł kształtowania stosunków umownych (od „klasycznego” prawa umów ${ }^{8}$ ). Dodatkowo jego rozproszenie i niejednorodny charakter sprawia (lub może sprawiać) niemałe trud-

i towarzystw inwestycyjnych - ustawa z dnia 27 maja 2004 roku o funduszach inwestycyjnych i zarządzaniu alternatywnymi funduszami inwestycyjnymi (tekst jedn. Dz.U. z 2020 r. poz. 95); w odniesieniu do spółdzielczych kas oszczędnościowo-kredytowych — ustawa z dnia 5 listopada 2009 roku o spółdzielczych kasach oszczędnościowo-kredytowych (tekst jedn. Dz.U. z 2019 r. poz. 2412 ze zm.); w odniesieniu do funduszy emerytalnych — ustawa z dnia 28 sierpnia 1997 roku — o organizacji i funkcjonowaniu funduszy emerytalnych (tekst jedn. Dz.U. z 2020 r. poz. 105 ze zm.).

5 Są to ustawy regulujące (także lub tylko) ochronę konsumenta usług finansowych przewidujące wyłącznie mechanizmy ochrony konsumenta w relacjach z przedsiębiorcą, a więc znajdujące zastosowanie jedynie w obrocie konsumenckim (jednostronnie profesjonalnym), między innymi: ustawa z dnia 30 maja 2014 roku o prawach konsumenta (tekst jedn. Dz.U. z 2019 r. poz. 683), dalej: u.p.k.; ustawa z dnia 23 sierpnia 2007 roku o przeciwdziałaniu nieuczciwym praktykom rynkowym (tekst jedn. Dz.U. z 2017 r. poz. 2070); ustawa z dnia 12 maja 2011 roku o kredycie konsumenckim (tekst jedn. Dz.U. z 2019 r. poz. 1083), dalej u.k.k.; ustawa o kredycie hipotecznym oraz o nadzorze nad pośrednikami kredytu hipotecznego i agentami; ustawa z dnia 23 października 2014 roku o odwróconym kredycie hipotecznym (tekst jedn. Dz.U. z 2016 r. poz. 786), dalej u.o.k.h.; a nawet ustawa z dnia 16 lutego 2007 roku o ochronie konkurencji i konsumentów (tekst jedn. Dz.U. z 2019 r. poz. 369, dalej: u.o.kik) w odniesieniu do przeciwdziałania praktykom naruszającym zbiorowe interesy konsumentów oraz stosowaniu niedozwolonych postanowień wzorców umów.

${ }^{6}$ Por. między innymi: J. Helios, Publicyzacja prawa prywatnego - prywatyzacja prawa publicznego w kontekście rozważań nad prawem europejskim, „Przegląd Prawa i Administracji” 92, 2013, s. 12 n.; A. Zieliński, Cywilnoprawne aspekty godzenia interesu indywidualnego z interesem publicznym, [w:] Prawa staja się prawem. Status jednostki a tendencje rozwojowe prawa, red. M. Wyrzykowski, Warszawa 2006, s. 99 n.

7 Dla przykładu można tu wskazać art. 47 u.k.k, art. 8 u.u.p., art.15 u.dz.u.

8 E. Rutkowska-Tomaszewska, Ochrona prawna klienta na rynku ushug bankowych, Warszawa 2013, s. 30. Zob. także P. Tereszkiewicz, Obowiazki informacyjne w umowach o ustugi finansowe. Studium instrumentów ochronnym w prawie prywatnym i prawie unijnym, Warszawa 2015, s. 33. 
ności w jego stosowaniu, przyczyniając się także do ograniczania skuteczności przewidywanych przez te regulacje prawne mechanizmów ochrony konsumenta usług finansowych.

\section{PRAWO OCHRONY KONSUMENTA USŁUG FINANSOWYCH - POJĘCIE I SPECYFIKA}

W ostatnich latach, po kryzysie finansowym zapoczątkowanym w 2008 roku, z uwagi na skalę nadużyć instytucji finansowych wobec klientów, oferowanie im skomplikowanych ,produktów finansowych”, brak przejrzystości w zakresie praktyk rynkowych instytucji finansowych $\mathrm{w}$ relacjach umownych z klientami, regulacja prawna umów o usługi finansowe wymagała ciągłych zmian, rozszerzania (w wymiarze zarówno podmiotowym, jak i przedmiotowym). Wzrost i intensywność regulacji prawnych przewidujących mechanizmy ochrony konsumenta (a nawet szerzej - klienta) usług finansowych jest wynikiem nieustannego i dynamicznego rozwoju rynku usług finansowych, niewydolności i niewystarczającego charakteru dotychczasowych regulacji prawnych ${ }^{9}$.

Szczególny charakter ochrony konsumenta usług finansowych i tym samym konieczność odrębnej regulacji prawnej usług finansowych wynikającej z ich specyfiki oraz zagrożeń i ryzyka, jakie za sobą niosą, podkreślony został przez dyrektywę $2011 / 83^{10}$. Przejawem realizacji tego założenia są wskazane akty prawa unijnego i krajowego (ustawy sektorowe i konsumenckie) wprowadzające mechanizmy ochrony nie tylko konsumenta, ale nawet szerzej — klienta ${ }^{11}$ usług finan-

9 Por. E. Rutkowska-Tomaszewska, Ustugi finansowe - dobrodziejstwo i (czy) zagrożenie dla konsumentów? Czy ochrona konsumenta ushug finansowych jest obecnie efektywna $i$ wystarczajaca?, [w:] Ochrona konsumenta na rynku ustug, red. M. Jagielska, E. Sługocka-Krupa, K. Podgórski, Warszawa 2016, s. 29.

10 Dyrektywa 2011/83 - dyrektywa Parlamentu Europejskiego i Rady 2011/83/UE z dnia 25 października 2011 roku w sprawie praw konsumentów (Dz.Urz. UE L 304 z 22.11.2011 r., s. 64).

11 W regulacjach ochronnych zakres pojęcia „klient” jest różny. Zazwyczaj klientem jest klient w ogóle lub jedynie nieprofesjonalny uczestnik rynku finansowego, na rzecz którego instytucja finansowa świadczy usługi, który odpowiada definicji klienta detalicznego nieposiadającego doświadczenia i wiedzy pozwalających na podejmowanie właściwych decyzji i ocenianie związanego z nimi ryzyka. Można tutaj wskazać następującą definicję: „każda osoba fizyczna lub prawna, na której rzecz firma inwestycyjna świadczy usługi inwestycyjne lub dodatkowe" (art. 4 ust. 1 pkt 9 dyrektywy 2014/65), przeniesioną do ustawy o obrocie instrumentami finansowymi (art. 3 pkt 39b i 39c u.o.i.f.), do której odwołują się również inne akty prawne, na przykład ustawa Prawo bankowe (art. 4 pkt 42, 43), ustawa o dystrybucji ubezpieczeń (art. 3 ust. 1 pkt 10). Szerzej: E. Rutkowska-Tomaszewska, Zakres podmiotowy ochrony klienta i jej mechanizmy na tle regulacji dotyczacych dystrybucji ubezpieczeń, [w:] Dystrybucja uslug ubezpieczeniowych. Wybrane zagadnienia prawne, red. B. Gnela, M. Szaraniec, Warszawa 2017, s. 83-107. 
sowych, które tworzą prawo usług finansowych, a w jego ramach konsumenckie prawo rynku finansowego (prawo ochrony konsumenta usług finansowych) ${ }^{12}$.

Niezależnie od tendencji do rozszerzania zakresu podmiotowego ochrony na rynku usług finansowych konsumencki status klienta instytucji finansowej ma znaczenie dla instytucji niedozwolonych klauzul umownych ${ }^{13}$ (między innymi przesłanek wiązania wzorcami umownymi, sposobu interpretacji niejednoznacznych postanowień wzorców umownych ${ }^{14}$, skutków prawnych posługiwania się nimi — w tym kontekście zakazu ich stosowania w ustawie o ochronie konkurencji i konsumentów), rozszerzonych obowiązków informacyjnych, ograniczeń w zakresie swobody kształtowania treści umów, stosowania praktyk naruszających zbiorowe interesy konsumentów, w tym missellingu usług finansowych oraz nieuczciwych praktyk rynkowych. Wynika to z przyjętego przez ustawodawcę unijnego i krajowego założenia, że podmioty działające profesjonalnie na rynku finansowym, świadcząc na rzecz klientów usługi, mają przewagę nad konsumentem, a także innym niż konsument klientem, który profesjonalistą nie jest.

Ponadto specyfika usług finansowych powoduje, że regulacje prawne odnoszące się do nich nie ograniczają się jedynie do cywilnoprawnych mechanizmów prawa umów, zwłaszcza zaś zasady swobody umów, gdyż są nieadekwatne do oceny tych usług i zachowań instytucji finansowych w relacjach z konsumentem, a ,zasada pacta sunt servanda traci na znaczeniu, obowiązek rozważnego działania stron umowy ustępuje zasadzie skutecznej, efektywnej ochrony konsumenta $^{15}$ ". Oznacza to ingerencję w swobodę umów i jednocześnie przyjęcie zasady, że ochrona konsumenta usług finansowych wymaga regulacji szczególnej, stanowiącej odstępstwo nie tylko od dotychczasowych regulacji prywatnoprawnych, ale nawet od ogólnych reguł ochrony konsumentów na rynku.

W ustawach sektorowych rozbudowywana jest materia prywatnoprawna dotycząca umów o usługi finansowe, praw i obowiązków stron ze względu na potrzebę ochrony klienta, a zwłaszcza konsumenta (dotyczy to zwłaszcza usług bankowych,

12 Por. E. Fojcik-Mastalska, Prawo rynku finansowego w systemie prawa, [w:] Prawo rynku finansowego. Doktryna, instytucje, praktyka, red. A. Jurkowska-Zeidler, M. Olszak, Warszawa 2016, s. 23-24.

13 Od dnia 1 lipca 2020 roku wchodzi w życie „nowy” przepis (art. $385^{5}$ k.c.), który rozszerza stosowanie przepisów art. $385^{1}-385^{3}$ k.c. i tym samym ochrony przed klauzulami abuzywnymi na inne niż konsument osoby fizyczne zawierające umowę bezpośrednio związaną z jej działalnością gospodarczą, gdy z treści tej umowy wynika, że nie ma ona dla niej charakteru zawodowego wynikającego w szczególności z przedmiotu wykonywanej przez nią działalności gospodarczej, udostępnionego na podstawie przepisów o Centralnej Ewidencji i Informacji o Działalności Gospodarczej.

$14 \mathrm{~W}$ zakresie umów ubezpieczenia w ustawie o działalności ubezpieczeniowej jest inaczej, gdyż „postanowienia umowy ubezpieczenia, ogólnych warunków ubezpieczenia oraz innych wzorców umowy sformułowane niejednoznacznie interpretuje się na korzyść ubezpieczającego, ubezpieczonego lub uprawnionego z umowy ubezpieczenia" (art. 15 ust. 5 u.dz.u.).

15 E. Rutkowska-Tomaszewska, Ochrona prawna klienta ..., s. 30; E. Łętowska, Prawo umów konsumenckich, Warszawa 2002, s. 3-5. 
płatniczych, inwestycyjnych, ubezpieczeniowych, kredytowych). W ustawach konsumenckich rozbudowywane są przepisy regulujące zasady $i$ wymogi podejmowania oraz prowadzenia działalności przez kredytodawców i pośredników kredytowych (dotyczy to ustawy o kredycie konsumenckim i ustawy o hipotecznym kredycie konsumenckim).

Typowymi mechanizmami ochrony konsumenta usług finansowych są: rozbudowane obowiązki informacyjne instytucji finansowych, wymogi formułowane wobec informacji przekazywanych konsumentom ${ }^{16}$ oraz (czasem) szczególne sankcje za ich niedochowanie (co jednak jest rzadkością) ${ }^{17}$, szczegółowa regulacja ustawowa praw i obowiązków stron umów o usługi finansowe, ze wskazaniem, że postanowienia umowne, mniej korzystne niż te przewidziane w ustawie, są niewiążące lub nieważne i w ich miejsce stosuje przepisy tych ustaw, szczególne uprawnienia, między innymi przedterminową spłatę kredytu konsumenckiego i konsumenckiego kredytu hipotecznego oraz związane z nią uprawnienie do proporcjonalnego obniżenia całkowitego kosztu kredytu, prawo do odstąpienia od umowy, nakaz adekwatności i odpowiedniości usługi do potrzeb klienta, obowiązek przeprowadzenia badania klienta, przepisy ograniczające dopuszczalność pobierania lub wysokość opłat i prowizji za poszczególne usługi finansowe, przepisy dotyczące odsetek maksymalnych czy maksymalnych pozaodsetkowych kosztów kredytu konsumenckiego i konsumenckiego kredytu hipotecznego.

Zauważalne jest także przejmowanie do regulacji umów o usługi finansowe nie tylko konsumenckich rozwiązań, typowych dla ustaw konsumenckich, i tym samym rozszerzanie ich na stosunki pozakonsumenckie (między innymi obowiązki informacyjne, odwrócony rozkład ciężaru dowodu, nakaz transparencji, szczególne uprawnienia konsumenta), czego przykładem są rozwiązania przyjęte chociażby w ustawie o usługach płatniczych, ustawie o działalności ubezpieczeniowej i reasekuracyjnej, ustawie o dystrybucji ubezpieczeń czy ustawie o obrocie instrumentami finansowymi.

16 W przepisach „ustaw sektorowych”, jak i tak zwanych „ustaw konsumenckich”, ustawodawca coraz częściej formułuje wymogi dotyczące informacji przekazywanych przez podmioty rynku finansowego konsumentom usług finansowych, takie jak: jasność, przejrzystość, kompletność, brak wprowadzenia w błąd. Wskazują często, by informacje te były przekazywane w zrozumiałej formie, w sposób umożliwiający zrozumienie charakteru oraz ryzyka związanego z usługą finansową, w postaci papierowej lub na trwałym nośniku informacji, w przejrzystej i czytelnej formie (na przykład art. 15 ust. 3 u.dz.u.; art. 7, 29 ust. 3 u.k.k.; art. 7, 10, 11 u.k.h.; art. 7 ust. 3, 9 u.d.u.; art. 22, 26 u.u.p.). Przy czym zakres przekazywanych informacji jest różny i zależy od rodzaju usługi finansowej (kredyt konsumencki, usługa ubezpieczeniowa, usługa inwestycyjna, usługa płatnicza).

17 Dla przykładu można tu wskazać znane już prawu konsumenckiemu sankcje w postaci sankcji kredytu darmowego (art. 45 u.k.k), braku możliwości rozwiązania umowy jako przejawu współodpowiedzialności za „złe” kredytowanie i uwikłanie się w stosunki kredytowe z „kłopotliwymi” kredytobiorcami (art. 22 u.k.h.), przedłużenie (wydłużenie) terminu odstąpienia od umowy (art. 53 ust. 2 u.k.k., art. 42 ust. 2 u.k.h., art. 41 u.p.k), a nawet tak zwane „,sankcyjne” prawo odstąpienia od umowy o usługę płatniczą (art. 26 ust. 5 u.u.p.). 
Jeśli idzie o przepisy ustaw konsumenckich przewidujących mechanizmy ochrony konsumenta usług finansowych, można wymienić następujące: w zakresie usług finansowych na odległość (rozdz. 1, 5 u.p.k.); w zakresie kredytu konsumenckiego (rozdz. 1-5 u.k.k.); w zakresie konsumenckiego kredytu hipotecznego (rozdz.1-6 u.k.h.); w zakresie odwróconego kredytu hipotecznego (rozdz. 1-5 u.o.k.h.). Poza tym, wprawdzie w odniesieniu do ochrony konsumenta w ogóle, w tym także usług finansowych, trzeba wskazać na przepisy w zakresie przeciwdziałania praktykom naruszającym zbiorowe interesy konsumentów i stosowaniu niedozwolonych klauzul umownych (dział III—V u.o.kik.); w zakresie przeciwdziałania nieuczciwym praktykom rynkowym — przepisy u.p.n.p.r.

Jeśli idzie o regulacje sektorowe (akty prawne rangi ustawowej) przewidujące mechanizmy ochrony konsumenta (a czasem szerzej - klienta) usług finansowych, można wymienić następujące: w zakresie usług płatniczych - ustawę o usługach płatniczych (dział I -IIIa u.u.p); w zakresie usług inwestycyjnych — ustawę o obrocie instrumentami finansowymi (dział IV, w szczególności art. 83-83j u.o.i.f., oraz tak zwane rozporządzenie mifidowskie ${ }^{18}$ ); w zakresie usług ubezpieczeniowych ustawę o działalności ubezpieczeniowej i reasekuracyjnej oraz ustawę o dystrybucji ubezpieczeń (art. 15-26 u.dz.u. oraz art. 7-16 u.d.u.); w zakresie usług świadczonych przez banki - ustawę Prawo bankowe (art. 54, 54a p.b., art. 56, 56a p.b., art. 69 ust. 3, art. 75 b p.b., art. 75 c p.b., rozdział 6a p.b.).

Dodatkowo, z uwagi na niewydolność funkcjonującego dotychczas sądowego modelu abstrakcyjnej kontroli klauzul abuzywnych, ustawą z dnia 5 sierpnia 2015 roku o zmianie ustawy o ochronie konkurencji i konsumentów oraz niektórych innych ustaw (Dz.U. z 2015 r. poz. 1634), która weszła w życie dnia 17 kwietnia 2016 roku, wprowadzono administracyjny model kontroli abstrakcyjnej niedozwolonych postanowień wzorców umowy sprawowany przez Prezesa UUOKIK ${ }^{19}$. Stosowanie niedozwolonych postanowień wzorców umów jest nową postacią zakazanej praktyki rynkowej w obrocie konsumenckim, a decyzje w tym zakresie wydaje Prezes UOKIK. Mają one „skutek wobec przedsiębiorcy, co do którego stwierdzono stosowanie niedozwolonego postanowienia umownego oraz wobec wszystkich konsumentów, którzy zawarli z nim umowę na podstawie wzorca wskazanego w decyzji” (art. 23d u.o.kik.). W ten sposób rozwiązano kontrowersje dotyczące rozszerzonej skuteczności orzeczeń (erga omnes), choć nie do końca problem skutecznego eliminowania niedozwolonych klauzul umownych z kon-

18 Rozporządzenie Ministra Finansów z dnia 30 maja 2018 roku w sprawie trybu i warunków postępowania firm inwestycyjnych, banków, o których mowa w art. 70 ust. 2 ustawy o obrocie instrumentami finansowymi, oraz banków powierniczych (Dz.U. z 2018 r. poz. 1112).

19 Szerzej na ten temat zamiast wielu A. Dobaczewska, Administracyjnoprawna kontrola postanowień wzorców umów konsumenckich, „Studia Prawno-Ekonomiczne” 100, 2016; K. Araczewska, Ł. Wroński, Wybrane zagadnienia ,konsumenckiej" nowelizacji ustawy o ochronie konkurencji i konsumentów, [w:] Ochrona klienta na rynku ushug finansowych w świetle aktualnych problemów i regulacji prawnych, red. E. Rutkowska-Tomaszewska, Warszawa 2017, s. 77-83. 
kretnych umów zawieranych z indywidualnym konsumentem ${ }^{20}$. Ta samą ustawą wprowadzono także nową kategorię zakazanej praktyki naruszającej zbiorowe interesy konsumentów (misselling usług finansowych), a regulacja ta jest wyrazem uznania potrzeby szczególnej ochrony konsumenta na rynku finansowym. Zgodnie z art. (art. 24 ust. 2 pkt 4 u.o.k.k.) jest nim proponowanie konsumentom nabycia usług finansowych, które nie odpowiadają potrzebom tych konsumentów ustalonym z uwzględnieniem dostępnych przedsiębiorcy informacji w zakresie cech tych konsumentów, lub proponowanie nabycia tych usług w sposób nieadekwatny do ich charakteru.

Nie sposób nie wspomnieć jeszcze aktu prawnego mającego znaczenie dla ochrony konsumenta na rynku finansowym o charakterze ustrojowo-procesowym, a mianowicie ustawie o rozpatrywaniu reklamacji przez podmioty rynku finansowego i o Rzeczniku Finansowym ${ }^{21}$. Wprowadziła ona jednolity system rozpatrywania reklamacji klientów ${ }^{22}$ przez podmioty rynku finansowego oraz instytucję Rzecznika Finansowego (jako organu ochrony klienta na rynku finansowym) ${ }^{23}$. Poza tym po globalnym kryzysie finansowym, którego przyczyny i skutki dowiodły, że na rynku finansowym konieczna jest efektywna ochrona konsumenta, nastąpiła rewizja dotychczasowego podejścia do niej ${ }^{24}$, a prawnej ochronie konsumenta usług finansowych w Unii Europejskiej nadano charakter strategiczny. Oprócz wzrostu regulacji ochronnych wyraża się ona także w konieczności umiejscowienia jej w kontekście stabilności finansowejej ${ }^{25}$ bezpieczeństwa rynku finansowego (rynku usług finansowych). Problematyka ta staje się zatem wyspecjalizowanym obszarem regulacji w ramach prawa rynku finansowego (konsumenckie prawo rynku finansowego), a także istotnym elementem nadzoru nad rynkiem finansowym (rozumianym szeroko w sensie podmiotowym i przedmiotowym) jako nadzoru nad samymi instytu-

${ }^{20}$ Co szczególnie znajduje odzwierciedlenie w sporach sądowych banków z konsumentami w odniesieniu do tak zwanych umów „frankowych" - umów o kredyt denominowany lub indeksowany do waluty innej niż polska, w związku z zastosowaniem w nich niedozwolonych klauzul waloryzacyjnych i indeksacyjnych.

21 Ustawa z dnia 5 sierpnia 2015 roku o rozpatrywaniu reklamacji przez podmioty rynku finansowego i o Rzeczniku Finansowym (tekst jedn. Dz.U. z 2019 r. poz. 2279 ze zm).

22 Jest nim tylko osoba fizyczna, nie mniej nie tylko konsument.

${ }^{23}$ Wyposażony jest on w różnego typu kompetencje do podejmowania działań, zarówno w indywidualnych sprawach konsumentów, tych o charakterze ogólnym.

${ }^{24}$ Szerzej por. J. Monkiewicz, M. Monkiewicz, W poszukiwaniu nowego paradygmatu ochrony konsumentów na rynkach finansowych, [w:] Ochrona konsumenta na polskim i międzynarodowym rynku finansowym, red. J. Monkiewicz, E. Rutkowska-Tomaszewska, Warszawa, s. 33-51 i powoływana tam literatura; B. Pachuca-Smulska, Nowy „paradygmat” ochrony konsumenta na rynku finansowym w świetle zmian regulacyjnych i instytucjonalnych po kryzysie finansowym 2007-2009, „Studia Prawno-Ekonomiczne” 109, 2018, s. 107-126.

25 Szerzej na temat stabilności finansowej i sposobów jej definiowania zamiast wielu M. Fedorowicz, O normatywnym pojęciu stabilności finansowej na rynku finansowym Unii Europejskiej w nowej architekturze nadzorczej, „Studia Europejskie” 2017, nr 4. 
cjami finansowymi świadczącymi usługi na rynku finansowym oraz nad ich praktykami rynkowymi wobec konsumentów. Dodatkowo, z uwagi na wpływ nadużyć instytucji finansowych wobec konsumentów na generowanie ryzyka systemowego, jego ochrona musi znaleźć swoje właściwe miejsce także w ramach nadzoru makroostrożnościowego (zarówno na poziomie unijnym, jak i krajowym ${ }^{26}$ ).

Powoduje to konieczność zwiększania aktywności organów nadzoru nad instytucjami finansowymi i ich praktykami rynkowymi, tak na poziomie regulacyjnym, jak i faktycznym, także poprzez włączenie organów ochrony konsumenta usług finansowych (Rzecznika Finansowego i Prezesa Urzędu Ochrony Konkurencji i Konsumentów ${ }^{27}$ ) w prace organów nadzoru nad rynkiem finansowym na szczeblu krajowym (Komisji Nadzoru Finansowego), w tym także makroostrożnościowego (Komitetu Stabilności Finansowej) ${ }^{28}$.

Jak widać z przedstawionych w ogólnym wymiarze (przeglądowym) całokształtu regulacji prawnych dotyczących ochrony konsumenta na rynku finansowym, konsumenckie prawo rynku finansowego (prawo ochrony konsumenta usług finansowych) jest niezwykle skomplikowane, rozproszone ${ }^{29}$ i niejednorodne w swym charakterze prawnym, a przez to niełatwe w stosowaniu. Niewątpliwie trudno je uznać za prawo prywatne lub prawo publiczne — jedynie jest ono prawem „wymykającym się" z utrwalonych podziałów prawa na gałęzie ${ }^{30}$ czy działy.

\section{WYZWANIA W ZAKRESIE STANOWIENIA, STOSOWANIA I EGZEKWOWANIA PRAWA OCHRONY KONSUMENTA USŁUG FINANSOWYCH (KONSUMENCKIEGO PRAWA RYNKU FINANSOWEGO) W KONTEKŚCIE ZAŁOŻENIA RACJONALNEGO USTAWODAWCY}

Nawet najlepsze prawo materialne przewidujące mechanizmy prawne ochrony konsumenta na rynku usług finansowych, dobre ,jakościowo”, bez skutecznego jego egzekwowania i stosowania nie jest w stanie zapewnić efektywnej i realnej ochrony konsumentom. Dodatkowo konieczne są odpowiednie regulacje o charakterze proceduralnym i ustrojowym, dzięki którym możliwe będzie re-

${ }^{26}$ Szerzej M. Fedorowicz, Ochrona konsumenta w kontekście działań unijnych organów nadzoru nad rynkiem finansowym, [w:] Ochrona konsumenta na polskim i międzynarodowym rynku..., s. $127-145$.

27 Od grudnia 2018 roku Prezes UOKIK jest członkiem Komisji Nadzoru Finansowego.

28 Szerzej na ten temat E. Rutkowska-Tomaszewska, Czy struktura instytucjonalna ochrony konsumenta na rynku ushg finansowych wymaga zmian? (kilka uwag wybranych w świetle nadużyć na rynku finansowym wobec konsumentów), „Przegląd Ustawodawstwa Gospodarczego” 2019, nr 11.

29 Por. E. Rutkowska-Tomaszewska, Ochrona konsumenta w zakresie umów dotyczacych ushug finansowych na odległość w ustawie o prawach konsumenta legislacyjnych, [w:] Ustawa o prawach konsumenta, red. D. Karczewska, M. Namysłowska, T. Skoczny, Warszawa 2015, s. 249-250.

${ }^{30}$ Por. E. Fojcik-Mastalska, op. cit. 
alne „wdrożenie” tych przepisów i ich stosowanie. Wzmocnienie proceduralne (przepisami prawa procesowego) i instytucjonalne (przepisami prawa ustrojowego) materialnego prawa ochrony konsumenta na rynku finansowym ${ }^{31}$ jest także wyrazem systemowego ujęcia tej materii i jednocześnie poważnym wyzwaniem dla racjonalnego ustawodawcy.

W przypadku interpretacji przepisów konsumenckiego prawa rynku finansowego nie zawsze rezultaty wykładni językowej są wystarczające, choć obowiązuje ogólna zasada, że należy opierać na jej wynikach i dopiero gdy ona zawodzi, można odwołać do wykładni systemowej i funkcjonalnej (celowościowej) ${ }^{32}$. Istotą wykładni celowościowej jest odwołanie się do celu regulacji prawnej, do jej ratio legis, po to, by określić sens przepisu prawnego ${ }^{33}$, gdyż nie jest możliwe do zaakceptowania takie znaczenie przepisu, które byłoby pozbawione jakiegokolwiek ratio legis ${ }^{34}$. Dopuszcza się zatem w drodze wykładni celowościowej korygowanie wyników wykładni językowej ${ }^{35}$, co wydaje się zabiegiem koniecznym w odniesieniu do przepisów konsumenckiego prawa rynku finansowego, w ślad za uznaniem jego szczególnego charakteru. W związku z tym, że przepisy te stanowią w większości przypadków implementację aktów prawa unijnego, należy, dokonując ich wykładni, spojrzeć z perspektywy przyczyn ich przyjęcia, podstawowych założeń i celów, które zawarte są w preambułach odpowiednich dyrektyw, a na poziomie aktów prawa krajowego - w uzasadnieniach do ich projektów.

Każda niejasna, niejednoznaczna sytuacja wywołana wątpliwościami interpretacyjnymi nie wpływa pozytywnie na kształtowanie właściwych praktyk rynkowych i kultury prawnej na rynku usług finansowych, nie służąc także zapewnieniu efektywnej i skutecznej ochrony konsumentom.

Istotne są — zgłaszane coraz częściej w literaturze przedmiotu — postulaty o dobre jakościowo prawo stanowione i stosowane ${ }^{36}$, by nie było ono wadliwe i wręcz niegodziwe w następstwie działań lub zaniechań człowieka ${ }^{37}$. Poprzez nieprzejrzystą i niejednoznaczną, budzącą wątpliwości regulację może dochodzić do „otwierania furtki” złym praktykom podmiotów, do których jest ona adresowana,

31 Por. E. Rutkowska-Tomaszewska, Aktualne trendy $i$ wyzwania w zakresie ochrony konsumenta na rynku finansowym. Dokad zmierza (powinna zmierzać) ochrona konsumenta? Kilka wybranych uwag, [w:] Ekonomia jako dyscyplina naukowa i kierunek ksztatcenia Aktualne trendy i pożądane zmiany, red. E. Rutkowska-Tomaszewska, W. Kwaśnicki, Warszawa 2020.

32 Zob. L. Morawski, Zarys wykładni prawa, Toruń 2010, s. 74-75. Tam też szerzej na temat reguł wykładni i dyrektyw preferencji oraz ich rodzajów z powołaniem się także na bogate orzecznictwo w tym zakresie (s. 71-91).

33 L. Morawski, op. cit., s. 158.

34 S. Grzybowski, System prawa cywilnego. Część ogólna, Wrocław 1985, s. 172.

35 Uchwała SN z dnia 16 marca 2007 roku (III CZP 9/07, OSNC 2008, Nr 2, poz. 19).

36 Szerzej na ten temat S. Wronkowska, Kilka uwag o odpowiedzialności za prawo, [w:] Ochrona strony słabszej stosunku prawnego. Ksiega jubileuszowa ofiarowana Profesorowi Adamowi Zielińskiemu, red. M. Boratyńska, Warszawa 2016, s. 29-37.

37 Ibidem, s. 29. 
i omijania pewnych rozwiązań w niej przyjętych, co z pewnością leży w sprzeczności z jej celem. Przejrzystość regulacji prawnych zatem, jak się wydaje, wpływa znacząco na przejrzystość praktyk rynkowych, właściwych, zgodnych z celem $\mathrm{i}$ istotą regulacji prawnych zachowań instytucji, do których jest adresowana. Pojawiające się „niedociągnięcia” językowe ustawodawcy nie mogą być wykorzystywane do ominięcia i wypaczenia pewnych instytucji ochronnych. Dlatego też niezwykle pożądaną i przydatną byłaby swoistego rodzaju „norma programowa” zawierająca cel regulacji, przez pryzmat której dokonywana byłaby wykładnia niejasnych, niejednoznacznie sformułowanych przepisów budzących wątpliwości. Konieczna jest także interpretacja zgodna $\mathrm{z}$ duchem prawa konsumenckiego i uwzględnieniem naczelnych jego zasad, co ma szczególne znaczenie w prawie ochrony konsumenta usług finansowych.

Wydaje się, że racjonalny ustawodawca powinien także przywiązywać ogromną wagę do tak zwanej ekonomicznej analizy prawa i wprowadzając pewne rozwiązania prawne, właściwie oceniać skutki ich wprowadzenia — z uwzględnieniem zakładanego celu.

Sporów interpretacyjnych dotyczących przepisów konsumenckich, w tym także odnoszących się do ochrony konsumenta usług finansowych, nie można zatem rozwiązywać, opierając się jedynie na wykładni językowej w oderwaniu od celu ustanowienia przepisów konsumenckiego prawa rynku finansowego. Przez jego pryzmat należy eliminować powstałe ewentualne wątpliwości interpretacyjne na gruncie wykładni językowej. W takich przypadkach trzeba sięgnąć do wykładni systemowej i celowościowej z perspektywy konsumenta, jako podmiotu, któremu ma być zapewniona realna i efektywna ochrona przez przepisy konsumenckie.

Ochrona słabszego (konsumenta) stała się faktem i jednocześnie ,problemem” w prawodawstwie i prawoznawstwie, wymaga „posłuszeństwa” prawu unijnemu ${ }^{38}$ i oznacza wymóg nowego podejścia do „utartych” schematów postrzegania stosunków umownych zarówno przez prawo prywatne, jak i publiczne. Prawo konsumenckie, w tym szczególnie konsumenckie prawo rynku finansowego, „przecina” te schematy, nie będąc ani jedynie prawem prywatnym, ani publicznym i oznacza bardzo często odstępstwo od tradycyjnych reguł dotychczas nim rządzących, stanowiąc poważne wyzwanie dla sądów i innych organów państwa, a także instytucji finansowych będących adresatami tych przepisów, zobowiązanych do ich przestrzegania.

Tylko jednolitość i przewidywalność rozstrzygnięć organów państwa jest gwarantem poszanowania praw wszystkich uczestników rynku finansowego, przejawem pewności prawa i bezpieczeństwa prawnego. Jest także jednym z najistotniejszych czynników funkcjonowania prawa w społeczeństwie i ochrony praw jednostki, w tym konsumenta usług finansowych.

38 Por. E. Łętowska, Prawo umów konsumenckich, Warszawa 2002, s. 3-5. 
Ochrona konsumenta na rynku usług finansowych (i nie tylko na nim) i tym samym przeciwdziałanie wszelkim nadużyciom wobec nich wymaga systemowego podejścia i spojrzenia z szerokiej perspektywy. Jednym z przejawów realizacji tego założenia mogłoby być wprowadzenie do kodeksu cywilnego całego rozdziału poświęconego umownym stosunkom konsumenckim i ustalenie uniwersalnych reguł. W ten sposób materia konsumencka zyskałaby kodeksową rangę i podkreślona zostałaby ranga regulacji konsumenckich w przepisach pozakodeksowych. Mógłby to być dobry sposób na właściwe stosowanie, interpretację i egzekwowanie prawa konsumenckiego uwzględniające jego specyfikę i tym samym odmienność i odstępstwo od ogólnych i tradycyjnych cywilnoprawnych reguł dotyczących stosunków umownych. W ślad za wprowadzeniem do niego definicji legalnej konsumenta (art. $22^{1}$ k.c.) konieczne jest określenie ogólnych zasad rządzących konsumenckim prawem umów, w tym także umów o usługi finansowe, uwzględniających potrzebę szczególnej ochrony, zwłaszcza ustanowienia szczególnych sankcji o charakterze cywilnoprawnym, niezależnie od innych przewidzianych w przepisach szczegółowych (sektorowych, czy tylko konsumenckich) sankcji o charakterze generalnym ${ }^{39}$, sformułowanie dyrektywy indywidualizacji i materializacji ochrony informacyjnej oraz zapewnienie wymogu jej odpowiedniości i adekwatności.

Egzekwowanie prawa ochrony konsumenta usług finansowych przez organy publiczne ma na celu zapewnienie, by usługa finansowa była dla konsumenta najbardziej odpowiednia, adekwatna do jego potrzeb, dostosowana do jego sytuacji finansowej, by była „szyta na jego miarę" ${ }^{40}$. Wnikliwej uwagi, zarówno na etapie stanowienia, jak i stosowania prawa ochrony konsumenta usług finansowych, wymaga także dorobek ekonomii behawioralnej i psychologii społecznej w kwestii niepełnej racjonalności wyboru dokonywanego przez konsumentów ${ }^{41}$.

Wciąż nasilają się i jednoznacznie nie są rozstrzygnięte przez doktrynę, orzecznictwo i praktykę problemy tak zwanych „kredytów frankowych” i skuteczne eliminowanie niedozwolonych klauzul z umów „frankowych”, umów ubezpieczenia $\mathrm{z}$ ubezpieczeniowym funduszem kapitałowym, problemy związane z interpretacją przepisu art. 49 u.k.k. dotyczącego proporcjonalnej obniżki całkowitego kosztu kredytu konsumenckiego w związku z jego przedterminowa

39 Por. E. Rutkowska-Tomaszewska, Idea ochrony konsumenta przez informacje na rynku ustug finansowych. Dokad zmierza? (powinna zmierzać?), [w:] Informacja na rynku ustug finansowych, red. E. Rutkowska-Tomaszewska, Warszawa 2019.

40 Por. ibidem.

41 Zob. szerzej T. Nieborak, Tworzenie i stosowanie prawa rynku finansowego a proces ekonomizacji prawa, Poznań 2016 i powoływana tam literatura; T. Zaleśkiewicz, Psychologia ekonomiczna, Warszawa 2013, s. 359; J. Wilkin, Ekonomia wolności i ekonomia zniewolenia. Kiedy ekonomia sprzyja poszerzaniu ludzkiej wolności, a kiedy ją ogranicza?, [w:] Modele ustroju społeczno-gospodarczego. Kontrowersje i dylematy, red. E. Mączyńska, Warszawa 2015. 
spłatą ${ }^{42}$. Znalazło to odzwierciedlenie w licznych skargach konsumentów oraz sporach sądowych konsumentów z instytucjami finansowymi i wyraźnie wskazuje na „niezwykłą żywotność” prawa ochrony konsumenta usług finansowych, a także duże problemy związane ze zrozumieniem i stosowaniem przepisów ochronnych. Aktualne orzecznictwo sądów powszechnych na tle konsumenckich sporów dotyczących stosunków z umów o usługi finansowe nie zawsze może świadczyć o zrozumieniu jego istoty i „ducha”, a z pewnością trudno mówić o ukształtowanej linii orzeczniczej. Niemałe znaczenie w zakresie egzekwowania tego prawa ma wymiar sprawiedliwości, gdyż w odniesieniu do indywidualnego konsumenta realizuje się sprawiedliwość — stosowanie i egzekwowanie przepisów przewidujących mechanizmy ochrony konsumenta usług finansowych. Niezrozumienie jego istoty i przyjmowanych przez niego mechanizmów ochronnych wpływa w znaczący sposób na stopień jego realnego stosowania i egzekwowania. Swoistego rodzaju „zmiana myślenia” organów wymiaru sprawiedliwości (zwłaszcza sądów powszechnych) $\mathrm{w}$ odniesieniu do sposobu postrzegania relacji umownych konsumenta $\mathrm{z}$ instytucją finansową, gdzie cywilnoprawne reguły kształtowania stosunków umownych są poważnie ograniczone przez rozbudowaną pozakodeksową regulację ochronną, staje się nieunikniona, jeśli nie chce się doprowadzić do faktycznego jej „uśmiercenia” i egzekucji zamiast egzekwowania.

W tym kontekście, przyjmując koncepcję szczególnego podejścia do ochrony konsumenta usług finansowych, pomysł powołania „specjalnych sądów” do rozstrzygania sporów na rynku finansowym ${ }^{43}$, poza obecną strukturą sądownictwa czy w jej ramach jako specjalnych wydziałów cywilnych, nie wydaje się kwestią pozbawioną sensu, a nawet skutkiem przyjętego założenia i wyrazem konsekwentnej realizacji konieczności powołania specjalnych sądów do rozstrzygania sporów na rynku finansowym.

Poprawa sytuacji konsumenta na rynku usług finansowych wymaga dużego zaangażowania organów administracji publicznej, właściwych w tych kwestiach

${ }^{42}$ Szerzej na ten temat zob. między innymi: M. Jabłoński, K. Koźmiński, Bankowe kredyty waloryzowane do kursu walut obcych w orzecznictwie sadowym, Warszawa 2018; A. Wachnicka, Redukcja kosztów $w$ razie przedterminowej spłaty kredytu konsumenckiego $w$ świetle orzeczenia TSUE C-383/18, „Internetowy Kwartalnik Antymonopolowy i Regulacyjny” 2019, nr 8; J. Pisuliński, Sankcja zamieszczenia w umowie niedozwolonego postanowienia w świetle dyrektywy 93/13/ EWG i orzecznictwa TSUE, [w:] Życie umowy konsumenckiej po uznaniu jej postanowienia za nieuczciwe na tle orzecznictwa TSUE, red. M. Romanowski, Warszawa 2017; E. Rutkowska-Tomaszewska, Wynagrodzenie kredytodawcy zwiazane z procesem kredytowania a regulacja prawna obniżenia całkowitego kosztu kredytu konsumenckiego w przypadku jego przedterminowej sptaty jako przejaw ochrony interesów ekonomicznych konsumenta, [w:] Ochrona klienta na rynku ustug finansowych...

$43 \mathrm{~W}$ odniesieniu do rynku kapitałowego szerzej J. Dybiński, A. Szumański, O potrzebie utworzenia $w$ Polsce wyspecjalizowanego sadu powszechnego dla rynku kapitałowego - analiza teoretyczna i prawnoporównawcza, „Studia Prawa Prywatnego” 1, 2019, cz. 1, „Studia Prawa Prywatnego" 2, 2019, cz. 2; a także E. Rutkowska-Tomaszewska, Czy struktura instytucjonalna... 
i kompetentnych w tych sprawach, do podjęcia odpowiednich działań i zastosowania środków prawnych w celu eliminowania niewłaściwych praktyk rynkowych instytucji finansowych.

\section{PODSUMOWANIE}

Zapewnienie skuteczności i efektywności prawa ochrony konsumenta usług finansowych jest dużym wyzwaniem dla organów publicznych egzekwujących i stosujących je. Przejawem wysokiej kultury prawnej i dyscypliny rynkowej jest stopień ich przestrzegania przez same instytucje finansowe świadczące usługi finansowe konsumentom, a znajomość tych regulacji, uprawnień i roszczeń z nich wynikających przez samych konsumentów ma również istotne znaczenie.

Realizacja tych założeń wymaga systemowego i kompleksowego podejścia oraz wysiłku i współpracy wielu podmiotów, w tym organów państwa, w celu zapewnienia i ugruntowania właściwej praktyki stosowania prawa ochrony konsumenta usług finansowych i dyscypliny rynkowej. Najpierw konieczne jest stanowienie przez racjonalnego ustawodawcę dobrego jakościowego prawa ochrony konsumenta usług finansowych funkcjonującego w ramach systemu prawa i w ramach prawa rynku finansowego (prawa usług finansowych czy prawa umów o usługi finansowe) oraz prawa konsumenckiego, z uwzględnieniem specyfiki usług finansowych i wymogu szczególnej ochrony konsumenta tychże usług. Pośpieszne i często spóźnione stanowienie przepisów prawa krajowego wprowadzających mechanizmy ochrony konsumenta na rynku finansowych, w związku z wymogiem implementacji odpowiednich aktów prawa unijnego, których wzrost jest w ostatnim czasie niezwykle dynamiczny, nie sprzyja realizacji założeń racjonalnego ustawodawcy. Trudno w takich warunkach o zachowanie spójności i integralności przepisów w systemie prawa, co ma niewątpliwie negatywny wpływ na ich stosowanie, a w konsekwencji na egzekwowanie prawa ochrony konsumenta na rynku finansowym ${ }^{44}$.

Ugruntowana praktyka właściwego stosowania prawa w celu ochrony konsumenta usług finansowych i realne uruchamianie przewidzianych w nim mechanizmów ochronnych wraz z sankcjami za ich nieprzestrzeganie (egzekwowanie prawa ochrony konsumenta usług finansowych), poprzez kształtowanie linii

44 Szerzej na temat niedociągnięć w zakresie stanowienia prawa rynku finansowego, w tym prawa ochrony konsumenta usług finansowych, patrz także: E. Rutkowska-Tomaszewska, Ochrona klienta na rynku..., s. 805 n.; Forum Debaty Publicznej, System stanowienia prawa w Polsce. Zielona Ksiega, Kancelaria Prezydenta Rzeczypospolitej Polskiej, Warszawa 2013; U. Kubicka, Dobre prawo po dobrych skutkach poznacie, https://www.obserwatorfinansowy.pl/tematyka/rynki-finansowe/dobre-prawo-po-dobrych-skutkach-poznacie/ (dostęp: 2.03.2020); M. Dzieciuch, Ocena polskiego procesu legislacyjnego na przykładzie ostatnich zmian w prawie rynków finansowych, „Internetowy Kwartalnik Antymonopolowy i Regulacyjny” 2018, nr 6 (7), s. 8-20. 
orzeczniczej, przyczynia się do eliminowania nieuczciwych praktyk rynkowych i innych nadużyć instytucji finansowych wobec konsumentów (zarówno w wymiarze indywidualnym, zbiorowym, jak i globalnym z punktu widzenia niekorzystnych zjawisk na rynku finansowym $)^{45}$. Poza tym pozytywnie może to wpływać na kształtowanie się dyscypliny rynkowej i etyki (aby „nie opłacało się” instytucjom finansowym naruszać przepisów ochronnych, a sankcje za ich nieprzestrzeganie były nieuchronne i dotkliwe).

Nawet najdalej posunięta ochrona konsumentów w przepisach prawa materialnego nie będzie miała znaczenia, jeśli nie będzie wdrażana w praktyce w efektywny i realny sposób przez właściwe stosowanie i wykładnię przepisów przewidujących mechanizmy ochrony, nakładających obowiązki informacyjne i wprowadzających ograniczenia swobody kształtowania treści umów o usługi finansowe, zarówno przez same podmioty zobowiązane do przekazywania informacji konsumentom, jak i organy publiczne egzekwujące ich właściwe przestrzeganie.

Niewątpliwie pozakodeksowe regulacje prawne wprowadzające wskazane mechanizmy ochrony konsumenta usług finansowych w znacznej mierze ograniczają swobodę umów w zakresie kształtowania treści tychże umów. W kontekście założenia racjonalnego ustawodawcy wydaje się „zabiegiem” koniecznym, by „materia” ta zyskała w ogólnym wymiarze miejsce w kodeksie cywilnym poprzez jej uporządkowanie (usystematyzowanie) i wprowadzenie pewnych reguł ogólnych, stanowiących wskazówki interpretacyjne do stosowania przepisów konsumenckiego prawa rynku finansowego. Niezrozumienie istoty i celu idei ochrony konsumenta na rynku usług finansowych wypacza ją, powodując, że staje się iluzoryczna i nieefektywna na etapie zarówno stosowania, jak i egzekwowania przepisów przewidujących ten obowiązek.

Pewność prawa jest bezpieczeństwem prawnym i jednym z najistotniejszych czynników funkcjonowania prawa w społeczeństwie i ochrony praw jednostki, w tym konsumenta i przedsiębiorcy-profesjonalisty, na rynku usług finansowych. Problemem jest nie zawsze najlepsza jakościowo i niespójna regulacja, która stwarza poważne bariery w zapewnieniu realnej ochrony konsumentom, która jedynie „na papierze” może być „martwą”, iluzoryczną formułą.

Kończąc rozważania dotyczące aktualnych problemów i wyzwań związanych ze stanowieniem i stosowaniem prawa ochrony konsumenta na rynku finansowym, autorka, w nieco żartobliwy, co nie oznacza niepoważny, sposób pozwala sobie stwierdzić, że obecny stan faktyczny ochrony konsumenta usług finansowych można porównać do „zabawy w kotka i myszkę”. Jeszcze bardziej tę sytuację oddaje tytuł znanej komedii w reżyserii Stanisława Barei pod tytułem Co mi

45 Por. E. Rutkowska-Tomaszewska, Current trends in consumer protection regulations in the financial services market in Poland, [w:] Consumer Rights Protection. Threats and Opportunities for Enhancing Consumer Awareness, red. S. Smyczek, Katowice 2020 (w druku). 
zrobisz, jak mnie złapiesz? Aby jednak konsumenckie prawo rynku finansowego nie było „martwą literą prawa”, musi być „wypełniane” w praktyce i stać się głęboko zakorzenioną w rzeczywistości społeczno-gospodarczej zasadą obowiązującego systemu prawa w Polsce.

\title{
CONSUMER PROTECTION LAW FOR FINANCIAL SERVICES IN THE LIGHT OF THE RATIONAL LEGISLATOR'S ASSUMPTION - SOME SELECTED COMMENTS
}

\begin{abstract}
Summary
Acts of Union and national law governing financial services are increasingly beginning to be comprehensive, as they contain not only standards governing the legal conditions under which financial institutions may be permitted to exercise them, but also standards that specifically regulate the rights and obligations of financial services contracts, specific rights of consumers and other mechanisms and instruments for protecting them, the legal nature of which may be questionable. They create consumer financial market law (financial services consumer protection law, and undoubtedly this may give rise to many disputes at the stage of application and interpretation of this law and also contribute to limiting the effectiveness of the mechanisms of financial services consumer protection envisaged by these regulations.

The aim of the study is to point out the specificity of this law and to emphasise the need for its proper establishment, application, and enforcement.
\end{abstract}

Keywords: consumer, consumer protection, financial service, financial services consumer protection law, enforcement of consumer protection law, application of consumer protection law

\section{BIBLIOGRAFIA}

Araczewska K., Wroński Ł., Wybrane zagadnienia , konsumenckiej” nowelizacji ustawy o ochronie konkurencji i konsumentów, [w:] Ochrona klienta na rynku usług finansowych w świetle aktualnych problemów i regulacji prawnych, red. E. Rutkowska-Tomaszewska, Warszawa 2017.

Dobaczewska A., Administracyjnoprawna kontrola postanowień wzorców umów konsumenckich, „Studia Prawno-Ekonomiczne” 100, 2016.

Dybiński J., Szumański A., O potrzebie utworzenia w Polsce wyspecjalizowanego sadu powszechnego dla rynku kapitałowego - analiza teoretyczna i prawnoporównawcza, „Studia Prawa Prywatnego" 1, 2019, cz. 1; 2, 2019, cz. 2.

Dzieciuch M., Ocena polskiego procesu legislacyjnego na przyktadzie ostatnich zmian w prawie rynków finansowych, „Internetowy Kwartalnik Antymonopolowy i Regulacyjny” 2018, nr 6 (7), s. $8-20$.

Fedorowicz M., Ochrona konsumenta w kontekście działań unijnych organów nadzoru nad rynkiem finansowym, [w:] Ochrona konsumenta na polskim i międzynarodowym rynku finansowym, red. J. Monkiewicz, E. Rutkowska-Tomaszewska, Warszawa 2019, s. 127-145.

Fedorowicz M., O normatywnym pojęciu stabilności finansowej na rynku finansowym Unii Europejskiej w nowej architekturze nadzorczej, „Studia Europejskie” 2017, nr 4. 
Fojcik-Mastalska E., Prawo rynku finansowego w systemie prawa, [w:] Prawo rynku finansowego. Doktryna, instytucje, praktyka, red. A. Jurkowska-Zeidler, M. Olszak, Warszawa 2016.

Forum Debaty Publicznej, System stanowienia prawa w Polsce. Zielona Ksiega, Kancelaria Prezydenta Rzeczypospolitej Polskiej, Warszawa 2013.

Grzybowski S., System prawa cywilnego. Część ogólna, Wrocław 1985.

Helios J., Publicyzacja prawa prywatnego - prywatyzacja prawa publicznego w kontekście rozważań nad prawem europejskim, „Przegląd Prawa i Administracji” 92, 2013.

Jabłoński M., Koźmiński K., Bankowe kredyty waloryzowane do kursu walut obcych w orzecznictwie sadowym, Warszawa 2018.

Kubicka U., Dobre prawo po dobrych skutkach poznacie, https://www.obserwatorfinansowy.pl/ tematyka/rynki-finansowe/dobre-prawo-po-dobrych-skutkach-poznacie/ (dostęp: 2.03.2020).

Łętowska E., Prawo umów konsumenckich, Warszawa 2002.

Monkiewicz J., Monkiewicz M., W poszukiwaniu nowego paradygmatu ochrony konsumentów na rynkach finansowych, [w:] Ochrona konsumenta na polskim i międzynarodowym rynku finansowym, red. J. Monkiewicz, E. Rutkowska-Tomaszewska, Warszawa 2019.

Morawski L., Zarys wyktadni prawa, Torun 2010.

Nieborak T., Tworzenie i stosowanie prawa rynku finansowego a proces ekonomizacji prawa, Poznań 2016.

Nieprawidłowości na rynku finansowym a ochrona konsumenta. Raport Doradczego Komitetu Naukowego przy Rzeczniku Finansowym, Warszawa, wrzesień 2019, https://rf.gov.pl/pdf/DKN_ Raport_nieprawidlowosci_wrzesien2019.pdf.

Pachuca-Smulska B., Nowy „,paradygmat” ochrony konsumenta na rynku finansowym w świetle zmian regulacyjnych i instytucjonalnych po kryzysie finansowym 2007-2009, „Studia Prawno-Ekonomiczne" 109, 2018.

Pisuliński, J., Sankcja zamieszczenia w umowie niedozwolonego postanowienia w świetle dyrektywy 93/13/EWG i orzecznictwa TSUE, [w:] Życie umowy konsumenckiej po uznaniu jej postanowienia za nieuczciwe na tle orzecznictwa TSUE, red. M. Romanowski, Warszawa 2017.

Rutkowska-Tomaszewska E., Aktualne trendy $i$ wyzwania w zakresie ochrony konsumenta na rynku finansowym. Dokąd zmierza (powinna zmierzać) ochrona konsumenta? Kilka wybranych uwag, [w:] Ekonomia jako dyscyplina naukowa i kierunek kształcenia. Aktualne trendy i pożadane zmiany, red. E. Rutkowska-Tomaszewska, W. Kwaśnicki, Warszawa 2020.

Rutkowska-Tomaszewska E., Current trends in consumer protection regulations in the financial services market in Poland. Overview, [w:] Consumer Rights Protection. Threats and Opportunities for Enhancing Consumer Awareness, red. S. Smyczek, Katowice 2020 (w druku).

Rutkowska-Tomaszewska E., Czy struktura instytucjonalna ochrony konsumenta na rynku ustug finansowych wymaga zmian? (Kilka uwag wybranych w świetle nadużyć na rynku finansowym wobec konsumentów), „Przegląd Ustawodawstwa Gospodarczego” 2019, nr 11.

Rutkowska-Tomaszewska E., Idea ochrony konsumenta przez informacje na rynku ustug finansowych. Dokąd zmierza? (powinna zmierzać?), [w:] Informacja na rynku ustug finansowych, red. E. Rutkowska-Tomaszewska, Warszawa 2019.

Rutkowska-Tomaszewska E., Ochrona klienta na rynku usług bankowych, Warszawa 2013.

Rutkowska-Tomaszewska E., Ochrona konsumenta w zakresie umów dotyczacych ustug finansowych na odległość w ustawie o prawach konsumenta legislacyjnych, [w:] Ustawa o prawach konsumenta, D. Karczewska, M. Namysłowska, T. Skoczny, Warszawa 2015.

Rutkowska-Tomaszewska E., Ochrona prawna klienta na rynku usług bankowych, Warszawa 2013.

Rutkowska-Tomaszewska E., Ustugi finansowe - dobrodziejstwo i (czy) zagrożenie dla konsumentów? Czy ochrona konsumenta uslug finansowych jest obecnie efektywna $i$ wystarczajaca?, [w:] Ochrona konsumenta na rynku usług, red. M. Jagielska, E. Sługocka-Krupa, K. Podgórski, Warszawa 2016.

Przegląd Prawa i Administracji CXX, 2020, cz. 1 i 2

(C) for this edition by CNS 
Rutkowska-Tomaszewska E., Wynagrodzenie kredytodawcy zwiazane z procesem kredytowania a regulacja prawna obniżenia catkowitego kosztu kredytu konsumenckiego w przypadku jego przedterminowej splaty jako przejaw ochrony interesów ekonomicznych konsumenta, [w:] Ochrona klienta na rynku ustug finansowych w świetle aktualnych problemów i regulacji prawnych, red. E. Rutkowska-Tomaszewska, Warszawa 2017.

Rutkowska-Tomaszewska E., Zakres podmiotowy ochrony klienta i jej mechanizmy na tle regulacji dotyczacych dystrybucji ubezpieczeń, [w:] Dystrybucja ustug ubezpieczeniowych: wybrane zagadnienia prawne, red. B. Gnela, M. Szaraniec, Warszawa 2017.

Tereszkiewicz P., Obowiąki informacyjne w umowach o ustugi finansowe. Studium instrumentów ochronnych w prawie prywatnym i prawie unijnym, Warszawa 2015.

Wachnicka A., Redukcja kosztów w razie przedterminowej spłaty kredytu konsumenckiego w świetle orzeczenia TSUE C-383/18, „Internetowy Kwartalnik Antymonopolowy i Regulacyjny” 2019, nr 8.

Wilkin J., Ekonomia wolności i ekonomia zniewolenia. Kiedy ekonomia sprzyja poszerzaniu ludzkiej wolności, a kiedy ją ogranicza?, [w:] Modele ustroju społeczno-gospodarczego. Kontrowersje i dylematy, red. E. Mączyńska, Warszawa 2015.

Wronkowska S., Kilka uwag o odpowiedzialności za prawo [w:], Ochrona strony słabszej stosunku prawnego. Ksiega jubileuszowa ofiarowana Profesorowi Adamowi Zielińskiemu, red. M. Boratyńska, Warszawa 2016.

Zaleśkiewicz T., Psychologia ekonomiczna, Warszawa 2013.

Zieliński A., Cywilnoprawne aspekty godzenia interesu indywidualnego z interesem publicznym, [w:] Prawa stają się prawem. Status jednostki a tendencje rozwojowe prawa, red. M. Wyrzykowski, Warszawa 2006. 